\title{
Penerapan Interpretive Structural Modeling (ISM) Dalam Penentuan Elemen Pelaku Pengelolaan Tanaman Terpadu (PTT) Padi Sawah Menuju Pertanian Berkelanjutan Di Kabupaten Merauke
}

\section{Implementation of Interpretive Structural Modeling (ISM) In Determination of Integrated Planning Management Element (PTT) of Women Towards to Sustainable Agriculture in Merauke District}

\author{
Fransiskus Palobo $^{{ }^{*}}$ dan Yuliantoro Baliadi ${ }^{2}$ \\ ${ }^{1}$ Balai Pengkajian Teknologi Pertanian (BPTP) Papua \\ ${ }^{2}$ Balai Penelitian Tanaman Aneka Kacang Dan Umbi Malang \\ *E-mail : frans.merauke@gmail.com
}

\begin{abstract}
Program modeling in the application and determination of key actors in integrated cropland rice management and resource management for policy making is critical and strategic towards sustainable agriculture development. the objective of this research is to get key element actors in determining integrated crop management (PTT) of paddy rice for sustainable agriculture. As an indicator element interpretive structural modeling (ISM) in this research using 5 (five) Indicator element that is 1) Role of government, 2) Purpose, 3) Main obstacle, 4) Requirement of a program, 5) Institution involved. Results of interpretive structural modeling (ISM) analysis indicate that integrated rice plant cultivation to sustainable agriculture is the role of government in making strategic plan program hence need to follow by making technical instruction. Achieve the objective of applying integrated cropland rice management using high yielding varieties with high productivity and favored by farmers. The need for integrated cropland rice management needs to have proper fertilizer subsidies, seed subsidies, improved irrigation infrastructure and additional capital. The main constraint of integrated crop management is the uncertain climate change so pest disease is still high and at the time of planting season gadu water difficulty. While the institutions involved should be well synergized between the agricultural service and the institute for agricultural technology assessment. Policy direction in the strategic plan program needs a short, medium and long-term strategic plan by related institutions so that the youth will be evaluated according to the action stage.
\end{abstract}

Keywords: Interpretive Structural Modeling, PTT Rice Field, Sustainable Agriculture

Disubmit :10 Oktober 2018; Diterima : 15 November 2018; Disetujui : 08 Januari 2019;

\section{PENDAHULUAN}

Pada dasarnya pengelolaan tanaman dan sumber daya terpadu (PTT) bukanlah suatu paket teknologi, akan tetapi lebih merupakan metodologi atau strategi, bahkan filosofi bagi peningkatan produksi melalui cara mengelola tanaman, Tanah, Air dan unsur hara serta organISMe pengganggu tanaman secara holistik dan berkelanjutan (Litbang, 2007). Pendekatan yang di tempuh dalam penerapan komponen PTT bersifat : 1) partisipatif, 2) dinamis, 3) spesifik lokasi, 4) keterpaduan, dan 5) sinergis antar komponen (Litbang, 2009). Pengelolaan tanaman terpadu (PTT) merupakan alternative pengelolaan padi secara intensif pada lahan sawah. Komponen-komponen pengelolaan tanaman terpadu seperti penglelolaan hama terpadu (PHT), hara terpadu, air terpadu dan gulma terpadu telah dipraktekkan pada beberapa tahun terakhir, namun pnelolaannya 
secara terpisah-pisah, maka hasilnyapun belum optimal Keterpaduan dalam PTT bukan hanya terbatas pada keterpaduan antara tanaman, sumberdaya produksi dan teknologi, namun harus melibatkan keterpaduan yang lebih luas yaitu : 1) keterpaduan antar instusi, 2) keterpaduan antar di siplin ilmu pengetahuan, dan (3) keterpaduan analisis dan interprestasi.

Penerapan PTT didasarkan pada empat prinsip (1) PTT bukan merupakan teknologi maupun paket teknologi tetapi merupakan suatu pendekatan agar sumber daya tanaman, lahan dan air dapat dikelolah sebaik-baiknya, (2) PTT memanfaatkan teknologi pertanian yang sudah dikembangkan dan diterapkan dengan memperhatikan unsur keterkaitan, sinergis antara teknologi, (3) PTT memperhatikan kesesuaian teknologi dengan lingkungan fisik maupun social- ekonomi petani, (4) PTT bersifat partisipatif yang berarti petani turut serta menguji dan memilih teknologi yang sesuai dengan keadaan setempat dan kemampuan petani melalui proses pembelajaran. Dalam upaya pengembangan PTT secara nasional, maka Departemen Pertanian melunjurkan sekolah lapang (SL) PTT dengan tujuan sebagai acuan dalam pelaksanaan SL-PTT padi dalam upaya peningkatan produksitivitas, produksi, pendapatn petani dan kesejahteraan petani padi di Indonesia. Program SL-PTT diharapkan dapat dilaksanakan di tingkat provinsi maupun kabupaten/kota yang memiliki potensi pengembangan padi sawah.

Balai Besar Penelitian Tanaman Padi (BBPTP) telah menginisiasi aplikasi PTT lahan sawah irigasi sejak 1999 di Sukamandi. Peningkatan hasil padi yang diperoleh dengan penerapan PTT berbeda menurut tingkat dan skala luas usaha. Pada tingkat penelitian dan demonstrasi dengan luasan terbatas (1 - 2,5 ha) melalui model PTT hasil padi dapat meningkat rata-rata $37 \%$, peningkatan tersebut berkurang menjadi sekitar 27\% dan 16\% masing-masing di tingkat pengkajian dengan luasan sekitar 1-5 ha dan di tingkat implementasi dengan luasan 40 -100 ha. selain itu, dengan PTT hasil gabah dan kualitas beras juga meningkat; biaya usahatani padi berkurang, kesehatan dan kelestarian lingkungan terjaga (Litbang, 2009). Sedangkan di beberapa provinsi tingkat pengkajian SL-PTT padi sawah hasil yang dicapai, Sumatra Barat 5 - 6,7 t/ha GKG, Papua 5 - 5,3 t/ha GKG, (Kabupaten

Merauke 5 - 5,24 t/ha GKG), Bali 5,7 - 6,4 t/ha GKG, Papua Barat 4 - 5,6 t/ha GKG (Litbang, 2015). PTT yang dilaksanakan di provinsi Papua lebih dominan di kabupaten Merauke lebih diarahan PTT Padi, karena sangat sesuai dengan agroekosistem sedangkan PTT kedelai dan jagung lebih diarakan di Kabupaten Jayapura, keerom dan Nabire. PTT yang dilaksanakan di Kabupaten Merauke permasalahan utama pada saat musim rendengan/ MT 1 benih mengalami keterlambat karena di penangkar belum siap sedangkan lahan sudah siap sehingga sebagian besar petani menggunakan benih tidak bersertifikat. Akibatnya pertumbuhan padi kurang seragam dan muda terserang hama penyakit. Sedangkan pada musim tanam ke 2 (dua) / musim gadu benih tidak menjadi permasalahan namun air menjadi kendala utama, pada saat pertanaman padi masa primordia air sudah habis diirigasi/embun sehingga padi mengalami puso akibatnya banyak yang mengalami kegagalan panen.

Pembangunan pertanian berkelanjutan merupakan kominten negara-negara dunia yang harus dipatuhi dan dilaksanakan. Pelaksanaan pembangunan pada masa lalu yang hanya menekankan tujuan kemajuan ekonomi telah berdampak kepada kerusakan lingkungan dan timbulnya masalah sosial. Pembangunan berkelanjutan adalah upaya sadar dan terencana yang memadukan aspek lingkungan, sosial dan ekonomi kedalam strategi pembangunan untuk menjamin keutuhan hidup serta keselamatan, kemampuan, kesejahertaan dan mutu hidup generasi masa kini dan generasi masa depan (undang-undang RI No.32 Tahun 2009).

Secara operasional, pembangunan berkelanjutan sebagai upaya memaksimalkan manfaat bersih pembangunan ekonomi dengan syarat dapat mempertahankan dan meningkatkan jasa, kualitas dan kuantitas sumber daya alam sepanjang waktu (Turner, 1996). Beberapa tantangan dapat dipecahkan apabila sektor pertanian membangun dan menggunakan pengetahuan dan informasi dengan lebih baik (Turner, 1996). Bahkan, pengetahuan merupakan faktor produksi dan pertumbuhan ekonomi (Little, S., 2002) (FAO and 
World Bank, 2000). Pengetahuan yang meningkat hanya didapatkan dari belajar maupun pembelajaran yang terjadi secara baik dalam suatu masyarakat.

The Agricultural Research Service (USDA) mendefinisikan pertanian berkelanjutan sebagai pertanian yang pada waktu mendatang dapat bersaing, produktif, menguntungkan, mengkonservasi sumber daya alam, melindungi lingkungan, serta meningkatkan kesehatan, kualitas pangan, dan keselamatan. Technical Advisory Committee of the CGIAR (TAC/CGIAR 1988) menyatakan pertanian berkelanjutan adalah pengelolaan sumber daya yang berhasil untuk usaha pertanian guna membantu kebutuhan manusia yang berubah sekaligus mempertahankan atau meningkatkan kualitas lingkungan dan melestarikan sumber daya alam.

Pertanian berkelanjutan (sustainable agriculture) adalah pemanfaatan sumber daya yang dapat diperbarui (renewable resources) dan sumber daya tidak dapat diperbaharui (unrenewable resources) untuk proses produksi pertanian dengan menekan dampak negatif terhadap lingkungan seminimal mungkin. Keberlanjutan yang dimaksud meliputi : penggunaan sumberdaya, kualitas dan kuantitas produksi serta lingkungnya. Proses produksi pertanian yang berkelanjutan akan lebih mengarah pada pengggunaan produk hayati yang ramah terhadap lingkungan (Kasumbogo, 2012). Pembangunan pertanian di Indonesia diarahkan menuju pembangunan pertanian yang berkelanjutan sebagai bagian dari implementasi pembangunan berkelanjutan (sustainable development). Pembangunan pertanian (termasuk pembangunan pedesaan) yang berkelanjutan merupakan isu penting stategis yang menjadi perhatian dan pembicaraan disemua negara dewasa ini. Pembangunan pertanian berkelanjutan selain sudah menjadi tujuan, tetapi juga sudah menjadi paradigma pola pembangunan pertanian (Wordpress, 2016) berkelanjutan disemua aspek kehidupan manusia, maka pada tahun 1992, semua pemimpin dunia bertemu dalam konferensi dunia di Rio de Janeiro, Brasil yang membahas konsep pembangunan berkelanjutan untuk semua aspek kehidupan sosial, ekonomi, budaya dan lingkungan yang terkenal dengan nama Agenda 21. Salah satu agenda 21 yang berkaitan langsung dengan sektor pertanian adalah program Sustainable Agriculture and Rural Development (SARD). Pesan moral untuk mewujudkan kondisi lingkungan yang lebih baik untuk semua generasi ini diterima secara universal oleh pemimpin dunia, sehingga pertanian berkelanjutan (sustainable agriculture) menjadi prinsip dasar kelestarian lingkungannya (Sumodiningrat, 2000). Tujuan penelitian ini adalah untuk mendapatkan pelaku-pelaku elemen kunci penentuan dalam pengelolaan tanaman terpadu padi sawah menuju pertanian berkelanjutan.

\section{METODE PENELITIAN}

\section{Lokasi dan Waktu Penelitian}

Penelitian dilaksanakan pada bulan Mei sampai Agustus 2016 di Kabupaten Merauke dengan pertimbangan bahwa Kabupaten Merauke merupakan sentra program sekolah lapang pengelolaan tanaman terpadu (SL-PTT) padi di Papua. Sejak program SL-PTT dilaksanakan di Papua dari tahun 2007-2014, kemudian berubah program ke G-PTT padi tahun 2015 sampai sekarang lebih pokus di kabupaten Merauke. Menurut (Saxena J.P., 1994) ada 9 (sembilan) elemen indicator Interpretive structural modeling (ISM). Namun dalam penelitian ini membatasi 5 (lima) elemen indicator dengan pertimbangan keterbatasan waktu dan biaya yaitu; 1) peran pemerintah, 2) tujuan,3) kendala utama, 4) kebutuhan dari program, 5) lembaga yang terlibat.

Selanjutnya, pemilihan narasumber dengan pertimbangan dan peran masing-masing sebagai berikut : 1) Badan Lingkungan Hidup Kabupaten Merauke mempunyai peran melihat dampak lindungan terhadap program PTT terutama mengenai penggunakan bahan kimia seperti pestisida dan pupuk anorganik. 2) Dinas Pertanian Kabupaten Merauke mempunyai peran penting anggaran program SL-PTT dari kementrian pertanian dialokasikan langsung ke Dinas Pertanian untuk dikelola untuk disalurkan ke petani. Biaya sekolah lapang PTT di setiap wilayah kerja penyuluh dengan membuat demplot laboraturin lapang sebagai 
tempat pertemuan petani mulai dari tahap pengolahan tanah sampai panen selama 8 (delapan) kali pertemuan. 3) Lembaga swadaya masyarakat Yasanto, mempunyai peran sebagai pemerhati dibidang pertanian khususnya ke petani asli Papua, sehingga kegiatan pertanian yang di programkan pertanian organik. Kegiatan PTT yang dilakukan di petani lokal yaitu PTT spesifik lokasi. Yasanto memiliki Sekolah Politeknik Pertanian sehingga saat praktek

lapangan di kegiatan program PTT. 4) Faperta Unmus Merauke, mempunyai peran sebagai tempat pembelajaran dan praktek lapang mahasiswa fakultas pertanian di kegiatan program PTT. Ada Kerjasama antara Unmus Merauke, dinas pertanian dan BPTP papua untuk mengsukseskan program PTT. 5) Balai Pengkajian Teknologi Pertanian(BPTP) Papua, mempunyai peran memyiapkan benih untuk display yang bersumber dari BB Padi sukamandi setiap tahun 4-5 varietas unggul baru. Sebagai narasumber sekolah lapang SL-PTT, dan memyiapkan materi juknis SL-PTT.

\section{Analisis Data.}

Teknik ISM merupakan salah satu teknik permodelan sistem untuk menangani kebiasaan yang sulit diubah dari perencana jangka panjang yang sering menerapkan secara langsung teknik penelitian operasional dan atau aplikasi statistik deskriptif. Data yang diperoleh berdasarkan hasil wawancara dengan para stakeholders di lapangan. Selanjutnya dilakukan analisis dengan menggunakan Interpretative Structural Model (ISM) pada dasarnya untuk menyusun hirarki setiap sub elemen pada elemen yang dikaji kemudian membuat klasifikasi ke dalam 4 (empat) sektor untuk menentukan sub elemen mana yang termasuk ke dalam variable menurut (Kholil, 2005) dan (Eriyatno, 1998): autonomous (sektor 1), dependent (sector 2), linkage (sektor 3), dan independent (sector 4) seperti terlihat pada Gambar 1.

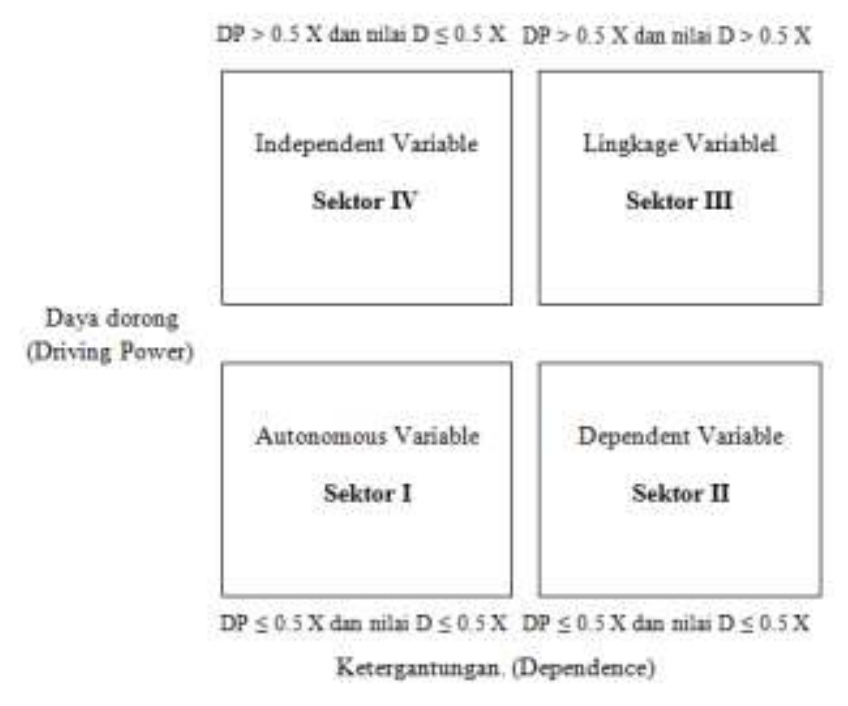

Gambar 1. Driving power- dependence

Setelah Structural self interaction matrix (SSIM) terisi sesuai pendapat responden, maka simbol (V, A, $\mathrm{X}, \mathrm{O})$ dapat digantikan dengan simbol (1 dan 0) dengan ketentuan yang ada sehingga dapat diketahui nilai dari hasil reachability matrix (RM). Menentapkan hubungan kontekstual antara subelemen yang terkandung adanya suatu pengarahan dalam terminologi subordinat yang menuju pada perbandingan berpasangan pendapat responden sebagai pakar menggunakan simbol $(\mathrm{V}, \mathrm{A}, \mathrm{X}, \mathrm{O})$ di mana :

$\mathrm{V} \mathrm{jika} \mathrm{e}_{\mathrm{ij}}=1$ dan $\mathrm{e}_{\mathrm{ji}}=0$

A jika $\mathrm{e}_{\mathrm{ij}}=0$ dan $\mathrm{e}_{\mathrm{ji}}=1$

$X$ jika $\mathrm{e}_{\mathrm{ij}}=1$ dan $\mathrm{e}_{\mathrm{ji}}=1$

$\mathrm{O}$ jika $\mathrm{e}_{\mathrm{ij}}=0$ dan $\mathrm{e}_{\mathrm{ji}}=0$ 
Keterangan :

Nilai eij $=1$ adalah ada hubungan kontekstual antara subelemen ke-i dan ke-j

Nilai eji $=0$ adalah tidak ada hubungan kontekstual antara subelemen ke-i dan ke-j

\section{HASIL DAN PEMBAHASAN}

\section{Analisis Peranan Pemerintah}

Hasil diskusi dengan pakar, pihak terkait penelitian di lapangan, elemen pemerintah terhadap 9 (sembilan) sub-elemen menunjukan bahwa realisasi penerapan dan strategi pengelolaan tanaman terpadu padi sawah. Pemerintah diharapakn membuat prioritas rencana strategis dan petunjuk teknis budidaya padi sesuai dengan prinsip-prinsip PTT padi sawah terutama terhadap komponen teknologi yang di gunakan untuk meningkatkan produktivitas, kemudian pemerintah juga diharapakan membangun sarana prasarana untuk memudahkan aktivitas kegiatan usahatani dilapangan. Menurut (Soerjono Soekanto, 2010) peranan lebih banyak menunjukkan suatu fungsi, penyesuaian diri dan sebagai suatu proses, jadi tepatnya adalah seseorang menduduki suatu posisi atau tempat dalam masyarakat serta menjalankan suatu peranan pemerintah menyediakan untuk memperlancar proses produksi. Pada Gambar 2 memperlihatkan hasil olahan data kuisioner untuk elemen kunci peran pemerintah.

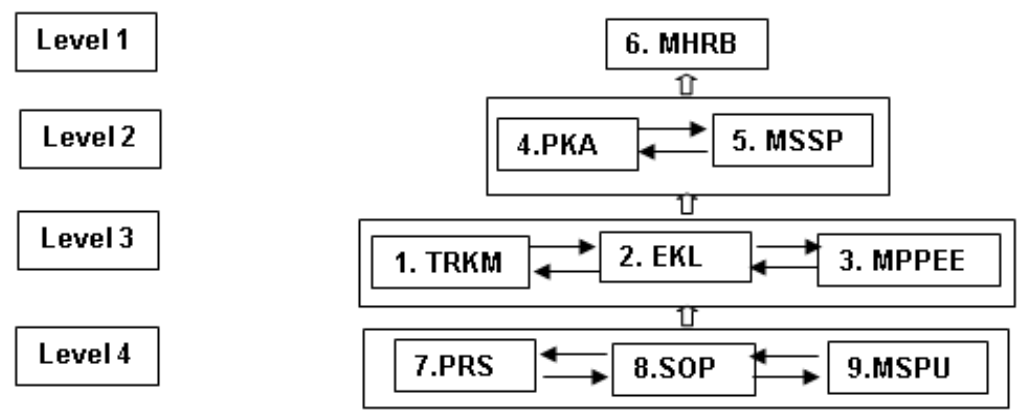

Gambar 2. Diagram hierarki dari sub elemen peran pemerintah dalam pengelolaan tanaman terpadu (PTT) padi sawah.

\section{Keterangan:}

1. Tata ruang Kabupaten Merauke (TRKM)

2. Evaluasi kesesuaian lahan (EKL)

3. Master plan pewilayahan ekologi, ekonomi dan social (MPPEES)

4. Penerapan kebijakan antar stakeholder (pencemaran pestisida, tata ruang dan yang terkait dengan pengelolaan residu bahan kimia) (PKAS)

5. Memberikan subsidi sarana produksi (MSSP)

6. Menjaga harga pasar beras pada saat panen raya (MHRB)

7. Prioritas rencana strategis (PRS)

8. Membuat Juknis teknologi budidaya padi sawah (SOP)

9. Membangun sarana prasarana dan usahatani (MSPU)

Gambar 2 terlihat bahwa elemen peran pemerintah yang merupakan elemen kunci dalam strategi dalam pengelolaan tanaman terpadu padi sawah di Kabupaten Merauke adalah prioritas rencana strategis (PRS), Membuat juknis teknologi budidaya padi sawah, membangun sarana prasarana dan usahatani (MSPU). Sehingga setiap peran pemerintah dalam kegiatan pertanian sangat dibutuhakan bimbingan teknis maupun rencana strategis dan penyediaan sarana prasarana untuk mempercepat lumbung pangan nasional dalam rangkah kedaulat pangan. Kemudian perlu diikut oleh peran pemerintah tata ruang Kabupaten 
Merauke (TRKM), evaluasi kesesuaian lahan (EKL), dan master plan pewilayahan ekologi, ekonomi dan sosial (MPPEES).

Untuk melihat nilai matriks elemen peran pemerintah yang berada di kolom tertinggi dan rendah dapat terlihat pada Gambar 2.

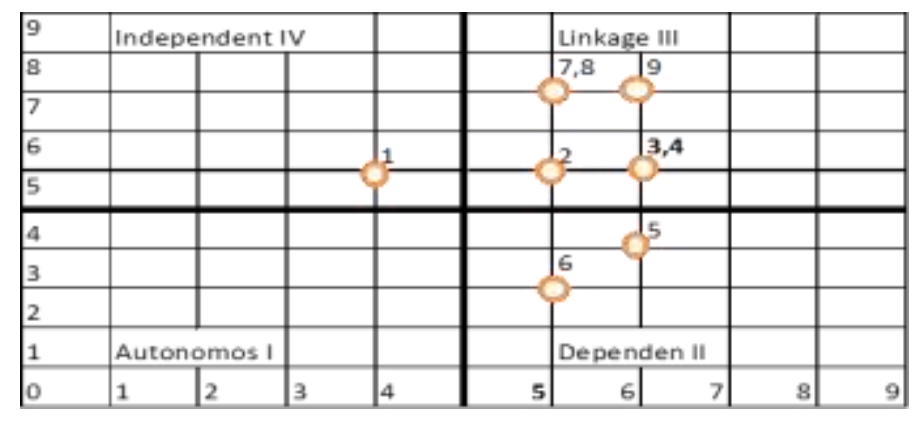

Gambar 2. Matriks driving power (DP) dan dependence (D) untuk elemen peran pemerintah dalam pengelolaan tanaman terpadu padi sawah dalam pembangunan berkelanjutan.

$\begin{array}{cl}\text { Sektor atau Kuadrant I } & \text { : Autonomous tidak terdapat sub elemen } \\ \text { Kuadrant II } & \text { : Dependent terdapat sub elemen 5 dan } 6 \\ \text { Kuadrant III } & \text { : Lingkage terdapat sub elemen 2,3,4,7, } 8 \text { dan } 9 \\ \text { Kuadrant IV } & \text { : Independent terdapat sub elemen } 1\end{array}$

Gambar 2 di atas dikelompokkan berdasarkan driving power (DP) dan dependence (D) yang terdiri dari 9 (Sembilan) sub elemen, dikelompokan kedalam 4 (empat) sektor. Gambar tersebut menunjukan bahwa sebagian sub elemen berada pada sektor lingkage 6 (enam) sub-elemen yaitu Evaluasi kesesuaian lahan (EKL), Master plan pewilayahan ekologi, ekonomi dan social (MPPEES), Penerapan kebijakan antar stakeholder (pencemaran pestisida, tata ruang dan yang terkait dengan pengelolaan residu bahan kimia) (PKAS), Prioritas rencana strategis (PRS), Membuat juknis teknologi budidaya padi sawah (SOP), Membuat sarana prasarana dan usahatani (MSPU). Dependent 2(dua) sub elemen yaitu memberikan subsidi sarana produksi (MSSP) dan menjaga harga pasar beras pada saat panen raya (MHRB). Sedangkan independent terdapat 1 (satu) sub elemen yakni tata ruang Kabupaten Merauke (TRKM) dan autonomous tidak terdapat sub elemen.

Berdasarakan nilai driving power dan pependence didapatkan matriks DP-D untuk elemen peran pemerintah yang dapat dilihat pada Gambar. 4 sub-elemen kunci dalam matriks DP-D berada pada posisi teratas dengan nilai driving power (DP) tertinggi, di sector lingkage. Matriks tersebut menunjukan bahwa sub-elemen prioritas rencana strategis (PRS), membuat Juknis teknologi budidaya padi sawah (SOP), membuat sarana prasarana dan usahatani (MSPU) berada pada sektor III (lingkage). Hal ini dikarenakan sub-elemen tersebut memiliki peran penting dalam segala aktivitas berusahatani dengan rencana strategis yang di prioritaskan baik sarana prasarana maupun petunjuk teknis budidaya padi dalam meningkatkan produktivitas dengan kekuatan dan daya dorong kuat tetapi ada ketergantungan pada sistem lain kuat. Pada sektor IV (independent) terdapat tata ruang Kabupaten Merauke (TRKM) artinya bahwa dibutuhkan peran pemerintah dalam kekuatan daya dorong kuat tetapi ketergantungan dalam sistem lain masih lemah. Untuk merealisasikan penerapan PTT padi sawah, peranan pemerintah menjadi sangat penting sehingga di tuntut untuk mengikuti dan mematuhi standar pemerintah dan persyaratan Negara sesuai dengan Undang-Undang Dasar 1945 (Herjanto, 2011). Sedangkan pada sektor II (dependen) terdapat 2 (dua) sub-elemen yaitu memberikan subsidi sarana produksi (MSSP), dan menjaga harga pasar beras pada saat panen raya (MHRB). Kekuatan pengeraknya lemah tetapi ketergantungan pada sistem lain kuat artinya bawah daya dorong 
pemberian subsidi sarana produksi dan menjaga harga pasar beras saat musim panen raya bisa dilaksanakan namun perlakuan oleh produksi padi sangat lemah sehingga melaksanakan ketergantungan sistem lain yang kuat memberikan subsidi harga beras saat panen raya.

\section{Analisis Tujuan}

Hasil analisis 12 (dua belas) sub-elemen tujunan penerapan pengelolaan tanaman terpadu (PTT) padi sawah menunjukan bahwa yang menjadi elemen kunci adalah penggunaan varietas padi unggul atau varietas padi berdaya hasil tinggi dan bernilai ekonomi tinggi yang sesuai dengan karakteristik lahan, lingkungan dan keinginan petani (PVPU). Varietas unggul adalah galur hasil pemuliaan dengan satu atau lebih keunggulan khusus, seperti potensi hasil tinggi, tahan terhadap hama dan penyakit, toleran terhadap cekaman lingkungan, mutu produksi tinggi, di sukai pasar dan/atau sifat-sifat unggul lainnya, serta telah di lepas pemerintah (Sarlan, A.R., S. Karsono, M. Yamin Samaullah, H. Sembiring, B.S. Effendi, 2012). Pada Gambar 3 dibawah ini memperlihatkan hasil olahan data kuisioner untuk elemen kunci tujuan pengelolaan tanaman terpadu padi sawah.

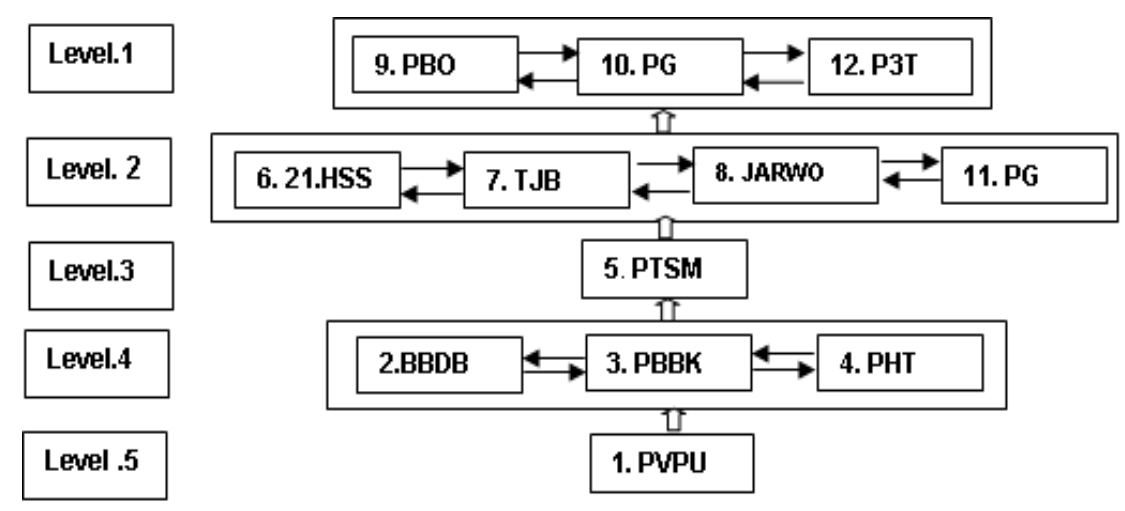

Gambar 3. Diagram hierarki dari sub tujuan pengelolaan tanaman terpadu (PTT) padi sawah dalam pembangunan pertanian berkelanjutan

\section{Keterangan :}

1. Penggunaan varietas padi unggul atau varietas padi berdaya hasil tinggi dan bernilai ekonomi tinggi yang sesuai dengan karakteristik lahan, lingkungan dan keinginan petani (PVPU)

2. Benih bermutu dan berlabel/bersertifikat (BBDB)

3. Pemupukan berimbang berdasarkan kebutuhan tanaman dan status hara tanah (PBBK)

4. Pengendalian hama dan penyakit secara terpadu (PHT).

5. Pengolahan tanah sesuai musim dan pola tanam (PTSM)

6. Penggunaan bibit muda ( $<21$ HSS $)$

7. Tanam dengan jumlah bibit terbatas yaitu antara $1-3$ bibit perlubang (TJB)

8. Tanam dengan jumlah bibit terbatas yaitu antara $1-3$ bibit perlubang (TJB)

9. Pengaturan populasi tanaman secara optimum (JARWO)

10. Pemberian bahan organik berupa kompos atau pupuk kandang serta pengembalian jerami ke sawah sebagai pupuk dan pembenah tanah (PBO

11. Pengairan berselang (intermiten irrigation) secara efektif dan efisien (PB)

12. Pengendalian gulma dengan landak atau gasrok (PG)

13. Panen dan penanganan pasca panen yang tepat. (P3T) 
Gambar 3 terlihat bahwa dalam elemen tujuan penerapan pengelolaan tanaman terpadu yang merupakan elemen kunci dalam strategi dalam pengelolaan tanaman terpadu padi sawah di kabupaten Merauke adalah penggunaan varietas padi unggul atau varietas padi berdaya berdaya hasil tinggi yang sesuai dengan karakteristik lahan, lingkungan dan keinginan petani (PVPU). Varietas yang unggul adalah varietas padi hibrida yang dibentuk menggunakan metode tiga galur, yaitu galur mandul jantan (GMJ) atau CMS (galur A), galur pelestari atau maintainer (galur B), dan tetua jantan yang sekaligus berfungsi sebagai pemulih kesuburan atau restorer (galur R). Ketiga galur (A; B; dan R) tersebut harus dibuat dan diseleksi secara ketat untuk membentuk hibrida unggul (Suprihatno B dan A.A. Daradjat, 2008). Kemudian perlu diikut oleh penerapan strategi pengelolaan tanaman terpadu padi sawah yaitu benih bermutu dan berlabel/bersertifikat (BBDB), pemupukan berimbang berdasarkan kebutuhan tanaman dan status hara tanah (PBBK), dan pengendalian hama dan penyakit secara terpadu (PHT).

Untuk melihat nilai matriks elemen tujuan program penerapan PTT padi sawah yang berada di kolom tertinggi dan rendah dapat terlihat pada Gambar 4.

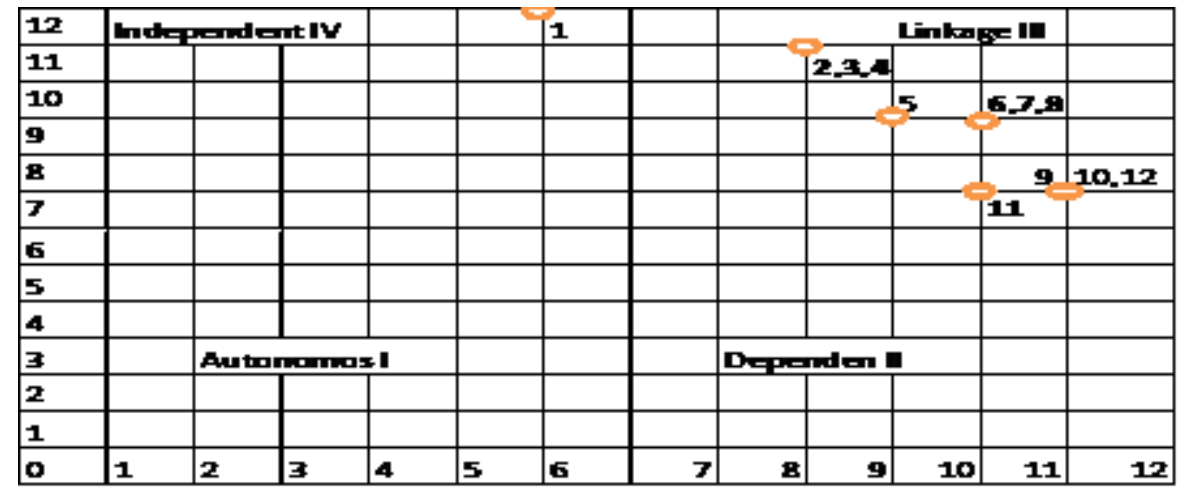

Gambar 4.Matriks Driving Power (DP) dan Dependence (D) untuk elemen tujuan dan strategi dalam pengelolaan tanaman terpadu padi sawah

Sektor atau Kuadrant I : Autonomous tidak terdapat sub elemen

Kuadrant II : Dependent tidak terdapat sub elemen

Kuadrant III : Lingkage terdapat sub elemen 2,3,4,5,6,7,8 ,9,10,11 dan 12

Kuadrant IV : Independent terdapat sub elemen 1

Gambar 4. dikelompokan berdasarkan berdasarkan driving power (DP) dan dependence (D) yang terdiri dari 12 (dua belas) sub elemen, dikategorikan kedalam 4 (empat) sektor. Pada sector independent terdapat satu sub elemen dan sector lingkage terdapat 11 (sebelas) sub elemen. Berdasarkan nilai driving power dan dependence didapatkan matriks DP-D untuk elemen tujuan penerapan dan strategi dalam pengelolaan tanaman terpadu padi sawah dapat dilihat pada Gambar 6. Sub elemen kunci dalam matriks DP-D berada pada posisi teratas dengan nilai driving power (DP) tertinggi, baik di sektor independent ataupun lingkage. Matriks tersebut menyatakan bahwa sub- elemen, (1) penggunaan varietas padi unggul atau varietas padi berdaya hasil tinggi dan bernilai ekonomi tinggi yang sesuai dengan karakteristik lahan, lingkungan dan keinginan petani berada pada sector keempat (independent) yang berarti sub elemen ini memiliki kekuatan penggerak yang besar dalam menunjang tujuan penerapan dan strategi dalam pengelolaan tanaman terpadu padi sawah dengan penggunaan vareitas unggul ini berada pada sektor independent artinya elemen ini ketergantungannya terhadap sistem yang lain lemah atau tidak bergantung pada sistem yang lain. Sedangkan pada sektor ketiga (lingkage) terdapat sub-elemen benih bermutu dan berlabel/bersertifikat (BBDB), pemupukan berimbang berdasarkan kebutuhan tanaman dan status hara tanah 
(PBBK), pengendalian hama dan penyakit secara terpadu (PHT). Pengolahan tanah sesuai musim dan pola tanam (PTSM), penggunaan bibit muda (<21 HSS), tanam dengan jumlah bibit terbatas yaitu antara 1-3 bibit perlubang (TJB), pengaturan populasi tanaman secara optimum (JARWO), pemberian bahan organik berupa kompos atau pupuk kandang serta pengembalian jerami ke sawah sebagai pupuk dan pembenah tanah (PBO), Pengairan berselang (intermiten irrigation) secara efektif dan efisien (PB), pengendalian gulma dengan landak atau gasrok (PG), panen dan penanganan pasca panen yang tepat (P3T). Pada lingkage ini terdapat 11 (sebelas) sub-elemen yang harus ditangani secara hati-hati oleh karena memliliki daya dorong yang kuat namun sangat bergantung terhadap elemen yang lain atau saling ketergantungan satu sama lainya.

Bila memperhatikan matriks driving power (DP) dan dependence (D) dari 4 (empat) kuadrant pada elemen tujuan ke 12 (dua belas) sub elemen pada kuadrant pertama tidak ada sub elemen, kuadrant kedua tidak ada sub elemen. Untuk kuadrant ketiga terdapat 11 (sebelas) sub-elemen artinya bahwa ke sebelas sub elemen ini harus dikaji secara hati-hati, sebab hubungan antara elemen lain tidak stabil sehingga setiap tindakan pada sub-elemen akan memberikan dampak terhadap sub-elemen lain dan pengaruh umpan baliknya akan memperbesar dampak. Kemudian pada kuadran keempat terdapat sub-elemen 1 (satu) menunjukan bahwa bagian dari sisa sistem yang bebas tidak bergantung pada sub-elemen lainya.

\section{Analisis Kebutuhan Program}

Hasil yang diperoleh dalam analisis elemen kebutuhan dapat dilihat pada Gambar 5. hasil analisis terhadap 8 (delapan) sub-elemen kebutuhan program tersebut menunjukkan bahwa yang menjadi elemen kunci yang memiliki nilai daya dorong paling tinggi yaitu, subsidi pupuk yang tepat (SPYT), subsidi benih (SB), memperbaiki/menyediakan irigasi/embun (MI), dan modal (M)

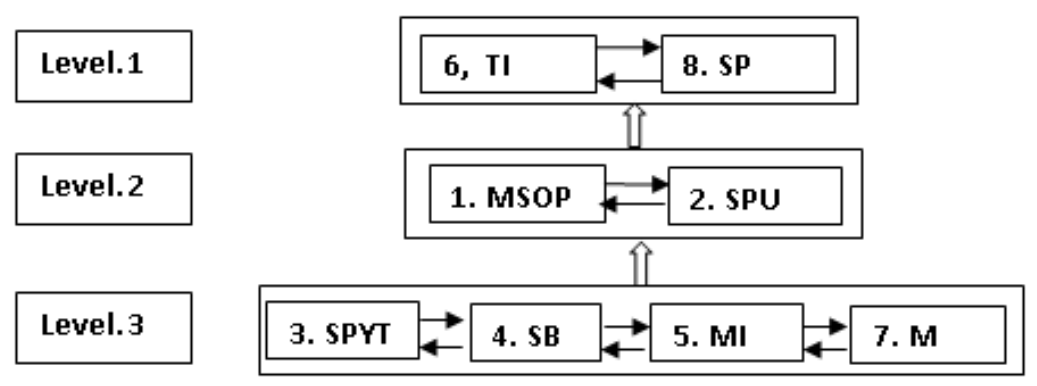

Gambar 5. Diagram hierarki dari sub kebutuhan dari program kebijakan penerapan pengelolaan tanaman terpadu (PTT) padi sawah

\section{Keterangan:}

1. Membutuhkan SOP/petunjuk teknis budidaya padi sawah (MSOP)

2. Transportasi / sarana prasarana jalan usahatani (SPU)

3. Subsidi pupuk yang tepat (SPYT)

4. Subsidi benih $(\mathrm{SB})$

5. Memperbaiki/menyediakan irigasi/embun (MI)

6. Teknologi inovasi (iklim, varietas dan PHT) (TI)

7. Modal (M)

8. $\quad$ Stabilitas politik (SP)

Gambar 5 memperlihatkan hasil olahan data kuisioner untuk elemen kunci kebutuhan. Penerapan Pengelolaan Tanaman Terpadu (PTT) Padi Sawah. Untuk melihat nilai matriks elemen kebutuhan penerapan PTT padi sawah yang berada di kolom tertinggi dan rendah dapat terlihat pada Gambar 6 . 


\begin{tabular}{|c|c|c|c|c|c|c|c|}
\hline 8 & Indepe & IV & & & Linkag & ge III & \\
\hline 7 & & & 3 & & $4,5,7$ & & \\
\hline 6 & & & 1 & & & 2 & \\
\hline 5 & & & & & & & \\
\hline 4 & & & & & & & \\
\hline 3 & & & 8 & & & & \\
\hline 2 & & & & & & 6 & \\
\hline 1 & Autono & & & & Deper & nden II & \\
\hline o & \begin{tabular}{l|l}
1 & 2 \\
\end{tabular} & 3 & 4 & 5 & 6 & $7 \mid$ & 8 \\
\hline
\end{tabular}

Gambar 6. Matriks driving power (DP) dan dependence (D) untuk elemen kebutuhan dari program kebijakan pengelolaan tanaman terpadu padi sawah di Kabupaten Merauke.

$\begin{array}{lll}\text { Sektor atau } & \text { Kuadrant I } & \text { : Autonomous terdapat sub elemen } 8 \\ & \text { Kuadrant II } & \text { : Dependent tidak sub elemen } 6 \\ \text { Kuadrant III } & \text { : Lingkage terdapat sub elemen 2,4,5 dan } 7 \\ \text { Kuadrant IV } & \text { : Independent terdapat sub elemen } 1 \text { dan } 3\end{array}$

Gambar 6 dikelompokan berdasarkan berdasarkan driving power (DP) dan dependence (D) yang terdiri dari 8 (delapan) sub elemen, dikategorikan kedalam 4 (empat) sektor. Pada sektor independent terdapat 2 (dua) sub elemen yaitu membutuhkan SOP/petunjuk teknis budidaya padi sawah (MSOP), subsidi pupuk yang tepat (SPYT). Sektor lingkage terdapat 4 (empat) sub elemen yaitu transportasi/sarana prasarana jalan usaha tani (SPU), subsidi benih (SB), memperbaiki/ menyediakan irigasi/embun (MI), dan modal (M).

Sub-elemen yang berada di sektor autonomous adalah sub-elemen memiliki daya dorong rendah dan ketergantungannya terhadap sistem lain lemah. Pada Gambar 6 terlihat bahwa sub-elemen stabilitas politik artinya bahwa jika stabilitas politik baik secara sosial maupun ekonomi untuk kelancaran roda pembangunan secara menyeluruh di berbagai bidang kehidupan. Sedangkan sektor dependent terdapat teknologi inovasi iklim, varietas dan PHT artinya bahwa merupakan bagian sisa dari sistem dan bebas sebagai peubah untuk sistem lain.

Berdasarkan nilai driving power dan dependence didapatkan matriks DP-D untuk elemen kebutuhan program pengelolaan tanaman terpadu padi sawah pada Gambar 6 sub-elemen kunci dalam matriks DP-D berada pada posisi teratas dengan nilai driving power (DP) tertinggi, baik di sektor independent pada subelemen subsidi pupuk yang tepat (SP) sedangkan sektor lingkage pada sub-elemen subsidi benih (SB), memperbaiki/ menyediakan irigasi/embun (MI), dan modal (M). Pupuk ialah pupuk bagi tanaman sama seperti makanan pada manusia, bahan yang diberikan ke dalam tanah baik yang organik maupun yang anorganik dengan maksud untuk mengganti kehilangan unsur hara dari dalam tanah dan bertujuan untuk meningkatkan produksi tanaman dalam keadaan faktor keliling atau lingkungan yang baik (Sutejo, 2002). Pupuk adalah material yang ditambahkan ke tanah atau tajuk tanaman dengan tujuan untuk melengkapi ketersediaan unsur hara. Bahan pupuk yang paling awal digunakan adalah kotoran hewan, sisa pelapukan tanaman, dan arang (Novizan, 2005).

Matriks driving power (DP) dan dependence (D) dari 4 (empat) kuadrant pada elemen kebutuhan program ke 8 (delapan) sub elemen pada kuadrant pertama terdapat 1 (satu) sub elemen artinya bahwa, kuadrant kedua tidak ada sub elemen. Untuk kuadrant ketiga terdapat 11 (sebelas) sub-elemen artinya bahwa ke sebelas sub elemen ini harus dikaji secara hati-hati, sebab hubungan antara elemen lain tidak stabil sehingga setiap tindakan pada sub-elemen akan memberikan dampak terhadap sub-elemen lain dan pengaruh umpan baliknya akan memperbesar dampak. Kuadran keempat terdapat sub-elemen 1 (satu) menunjukan bahwa bagian dari sisa sistem yang bebas tidak bergantung pada sub-elemen lainya. 


\section{Analisis Kendala Utama}

Hasil analisis pada kendala utama dalam Pengelolaan tanaman terpadi padi sawah terdapat 10 subelemen. Gambar 7 memperlihatkan hasil olahan data kuisioner untuk elemen kunci kendala utama Penerapan Pengelolaan Tanaman Terpadu (PTT) Padi Sawah.

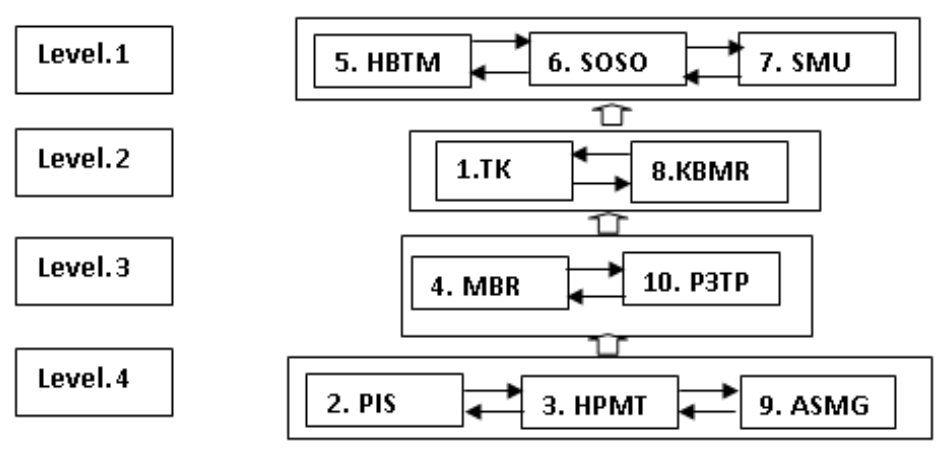

Gambar 7. Diagram hierarki dari sub kendala utama pengelolaan tanaman terpadu (PTT) padi sawah

\section{Keterangan :}

1. Tenaga kerja susa karena anak muda sekarang tidak tertarik bertani (TK)

2. Prediksi iklim sulit / tidak menentu (PIS)

3. Hama penyakit masih tinggi (HPMT)

4. Mutu beras rendah (MBR)

5. Harga beras tidak menentu kadang anjok saat panen raya (HBTM)

6. Hasil beras gilingan masih banyak yang patah/ soso (SOSO)

7. Sulit mendapatkan pupuk saat di butuhan/ kesulitan pupuk/ketersediaan pupuk tidak tepat waktu (SMU)

8. Kualitas benih masih rendah /karena penangkar tidak konsisten (KBMR)

9. Air sukar pada musim gadu (ASMG)

10. Penangan pasca panen terutama pengeringan (P3TP)

Gambar 7 terlihat bahwa dalam elemen kendala utama dari program pengelolaan tanaman terpadu yang merupakan elemen kunci dalam strategi dalam pengelolaan tanaman terpadu padi sawah di Kabupaten Merauke adalah prediksi iklim sulit/tidak menentu (PIS), hama penyakit masih tinggi (HPMT), dan air sukar pada musim gadu (ASMG). Kemudian diikuti dua subelemen dalam peningkatan kwalitas dan kuantitas maka perlu yaitu menjaga mutu beras jangan sampai rendah maka perlu penangan paska panen dengan baik dengan pengeringan.

Nilai matriks elemen kendala utama penerapan PTT padi sawah yang berada di kolom tertinggi dan rendah dapat terlihat pada Gambar 8. Gambar 8 di kelompokan berdasarkan driving power (DP) dan dependence (D) yang terdiri dari 10 sub-elemen, dikelompakan kedalam 4 sektor. Pada sektor independent terdapat 1 sub-elemen sedangkan sector lingkage terdapat 9 sub elemen kemudian dependent tidak terdapat sub elemen dan autonomous tidak terdapat sub elemen.

Berdasarkan nilai driving power dan dependence didapatkan matriks DP-D untuk eleman kendala utama program dapat dilihat pada gambar 8. sub-eleman kunci dalam matriks DP-D berada pada posisi teratas dengan nilai driving power (DP) tertinggi, di sektor lingkage. Matriks tersebut menunjukan bahwa sub-elemen prediksi iklim sulit/tidak menentu (PIS), kemudian hama penyakit masih tinggi (HPMT), dan air sukar pada musim gadu (ASMG) ketiga sub-elemen ini masih menjadi kendala utama untuk mempredeksi musin hujan atau musim kemarau sudah tidak akurat sehingga seranggan hama dan penyakit masih sukar di 
kendalikan dan pada saat memasuki musim gadu air sulit di dapatkan sehingga kekuatan daya dorong kuat tetapi ketergantungan pada sistem lain kuat maka perlu kajian mendalam. Iklim merupakan kejadiaan pada suatu daerah yang cukup luas dalam waktu, minimal 30 tahun yang sifat tetap namun karena adanya aktivitas manusia seperti urbanisasi, deforestasi serta industrisasi mempercepat perubahan iklim dalam waktu yang relatif cepat yang berakibat pada berbagai sektor kehidupan manusia salah satunya bidang pertanian. Walapun hasil penelitian berdasarkan jawaban narasumber tidak menjadi prioritas tentang harga beras saat panen raya. Namun perlu ada perhatian karena petani lebih cenderung menjual berasnya ke pedagang pengusaha pengilingan dengan harga yang bervariasi Rp.5000-6500 per-kilogram, seangkan acuaan pemerintah harga eceran teringgi seharusnya Rp.10.250 per-kilogram. Petani tidak langsung menjual ke bulog karena tidak bisa mengikuti standar aturan yang di tetapkan. Sedangkan pada sektor independent terdapat satu sub-elemen yaitu tenaga kerja susa karena anak muda sekarang tidak mau bertani memiliki usaha lain (TK) bahwa kekuatan daya dorong kuat tetapi ketergantungan pada sistem lain lemah.

\begin{tabular}{|c|c|c|c|c|c|c|c|c|c|}
\hline \multirow{2}{*}{\begin{tabular}{|l}
10 \\
9 \\
\end{tabular}} & \multicolumn{2}{|c|}{ Independent IV } & & & & \multicolumn{2}{|c|}{ Unkage al } & \multirow{2}{*}{ 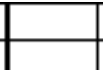 } & \\
\hline & & & & & & 2_3.9 & & & \\
\hline $\mathbf{B}$ & & & & & & & 10 & 4 & \\
\hline \multicolumn{10}{|c|}{5.8} \\
\hline \multicolumn{10}{|l|}{6} \\
\hline \multicolumn{10}{|l|}{5} \\
\hline \multicolumn{10}{|l|}{4} \\
\hline \multicolumn{10}{|l|}{3} \\
\hline $\mathbf{z}$ & \multicolumn{2}{|c|}{ Autonomos I } & & & & \multicolumn{3}{|c|}{ Dependen a } & \\
\hline 1 & & & & & & & & & \\
\hline $\boldsymbol{0}$ & 1 & $\mathbf{3}$ & 4 & 5 & 6 & $\boldsymbol{Y}$ & $\mathbf{z}$ & $\mathbf{g}$ & 10 \\
\hline
\end{tabular}

Gambar 8. Matriks driving power (DP) dan dependence (D) untuk elemen kendala utama program pengelolaan tanaman terpadu padi sawah.

\section{Sektor atau Kuadrant I : Autonomous tidak terdapat sub elemen \\ Kuadrant II : Dependent tidak terdapat sub elemen \\ Kuadrant III : Lingkage terdapat sub elemen 2,3,4,5,6,7,8,9 dan 10 \\ Kuadrant IV : Independent terdapat sub elemen 1}

\section{Analisis Lembaga yang Terlibat}

Berdasarkan hasil wawancara dengan pakar elemen yang terpengaruh diuraikan sebagai berikut yang terdiri dari 11 (sebalas) sub-elemen yaitu, (1) Dinas pertanian Kabupaten (DPK), (2) BPS Kabupaten (BPS), (3) Badan penyuluhan pertanian perikanan dan kehutanan Kabupaten (BP4K), (4) Pemda Bupati (PB), (5) Kepala Kampung (KP), (6) Babinsa (B), (7)Tokoh Adat/lembaga adat (TOGA), (8) Badan Litbang (BL), (9) Lembaga Ilmu penelitian Indonesia (LIPI), (10) Perguruan Tinggi (PT), dan (11) BPTP Propinsi. Dinas pertanian kabupaten yang merupakan pemilik wilayah yang memliki sumber daya manusia yaitu penyuluh dan penyuluh membawahi wilayah kerja penyuluhan pertanian (WKPP) sekaligus sebagai koordinator di satu kabupaten untuk melaksankan program di dukung oleh Balai pengkajian Teknologi Pertanian (BPTP) untuk menghasilkan inovasi teknologi untuk peningkatan produktivitas padi. Lembaga yang terlibat dalam pengelolaan tanaman terpadu (PTT) padi sawah ditampilkan pada diagram alir (Gambar 10) . 

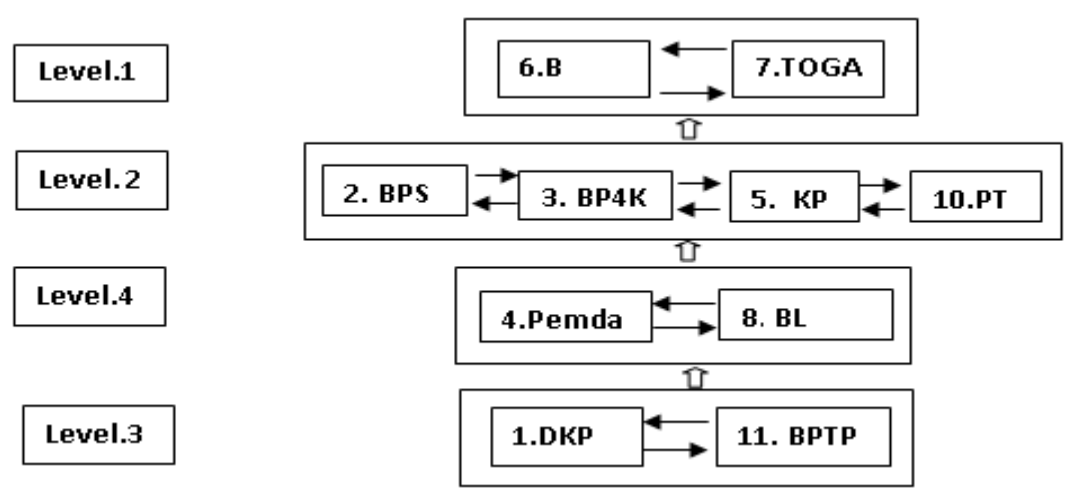

Gambar 10. Diagram hierarki dari sub Lembaga yang terlibat dalam pengelolaan tanaman terpadu (PTT) padi sawah

Keterangan .

1. Dinas Pertanian Kabupaten (DPK)

2. Badan Pusat Statistik Kabupaten (BPS)

3. Badan penyuluhan pertanian perikanan dan kehutanan Kabupaten (BP4K)

4. Pemda (Bupati) (PB)

5. Kepala Kampung (KP)

6. Babinsa (B)

7. Tokoh adat/lembaga adat (TOGA)

8. Badan litbang (BL)

9. Perguruan Tinggi (PT)

10. Lembaga Ilmu Pengetahuan Indonesia (LIPI)

11. Balai Pengkajian Teknologi Pertanian Propinsi (BPTP)

Pada Gambar 10. bahwa dalam elemen lembaga yang terlibat program pengelolaan tanaman terpadu yang merupakan elemen kunci dalam strategi dalam pengelolaan tanaman terpadu padi sawah di kabupaten Merauke adalah Badan Litbang Pertanian (BLP). Kemudian disusul pada elemen kunci kedua ada 4(empat) elemen yaitu Pemda (Bupati) (PB), Kepala Kampung (KP), Babinsa (B), Lembaga Ilmu Pengetahuan Indonesia (LIPI).

Untuk melihat nilai matriks elemen lembaga yang terlibat dalam penerapan PTT padi sawah yang berada di kolom tertinggi dan rendah dapat terlihat pada Gambar 11 dibawah ini.

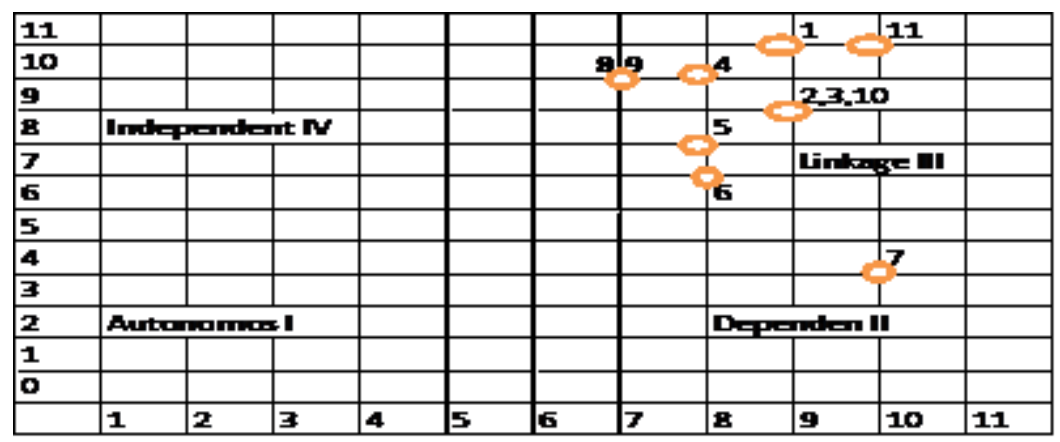

Gambar 11. Matriks Driving Power (DP) dan Dependence (D) untuk elemen lembaga yang terlibat dalam program pengelolaan tanaman terpadu padi sawah. 


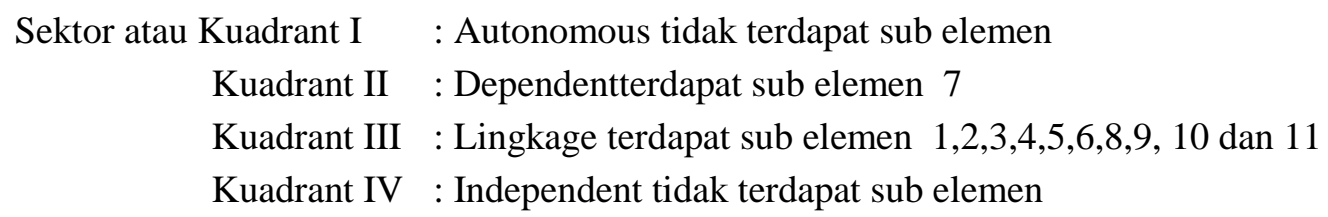

Pada Gambar 11.di kelompokan berdasarkan driving power (DP) dan dependence (D) yang terdiri dari 11 (sebelas) sub-elemen, dikelompakan kedalam 4 (empat) sektor. Pada sektor independent tidak terdapat sub-elemen sedangkan sektor lingkage terdapat 10 sub elemen kemudian Dependent terdapat 1 sub-elemen dan autonomos tidak terdapat sub-elemen.

Berdasarkan nilai driving power dan dependence di dapatkan matriks DP-D untuk eleman kendala utama program dapat dilihat pada gambar 12 (dua belas) sub-eleman kunci dalam matriks DP-D berada pada posisi teratas dengan nilai driving power (DP) tertinggi, di sektor lingkage matriks tersebut menunjukan bahwa sub-elemen dinas pertanian kabupaten (DPK) dan Balai Pengkajian Teknologi Pertanian Propinsi (BPTP) bahwa kekuatan daya dorong dan ketergantungan pada sistem lain kuat. Pada sektor yang sama berada pada Lingkage yaitu sub-elemen Badan Pusat Stasitik Kabupaten (BPS), Badan Penyuluhan Pertanian perikanan dan kehutanan Kabupaten (BP4K), Pemda Bupati (PB), Kepala Kampung, Babinsa (B), Badan Litbang (BL), LIPI Bogor (LIPI), Perguruan Tinggi (PT) ini artinya bahwa kekuatan daya dorong dan ketergantungan pada sistem lain kuat sehingga perlu dikajian secara hati-hati sebab hubungan antara elemen tidak stabil /lemah. Setiap tingkatan pada sub-elemen akan memberikan dampak terhadap sub-elemen lainnya dan pengaruh umpan baliknya dapat membesar dampak. Sedangkan sektor dependent terdapat subelemen tokoh adat/lembaga adat (TOGA) dikarenakan kekuatan penggerak atau daya dorong lemah tetapi ketergantungan pada sistem lain sangat kuat, artinya bahwa menfasilitas dalam program sangat lemah tetapi mempunyai wilayah adat yang kuat sebagi pengerak/penghubung untuk menghindari hal-hal yang tidak di inginkan.

\section{KESIMPULAN}

Pengelolaan tanaman terpadu padi sawah untuk mendapatkan pelaku sebagai elemen kunci dengan interpretif structural modeling (ISM). Perlu adanya daya dorong peran pemerintah dalam merencanakan program dengan membuat petunjuk teknis budidaya padi sawah, dan kesiapan sarana prasarana usahatani. Pelaku lain yang juga mempunyai daya dorong tinggi untuk mendorongjalannya usahatani padi dengan menyiapkan varietas unggul baru yang adaptif sesuai karakteristik lahan, lingkungan dan disukai pasar/petani. Pada kebutuhan program pada level tertinggi sektor keempat memperbaiki/menyediakan salur irigasi dan embun, sektor ketiga subsisdi pupuk yang tepat, subsidi benih dan perlu tambahan modal berada pada posisi lingkage ada terhubungan sehingga perlu daya dorong yang kuat satu sama lainnya. Dengan adanya kendala utama selama PTT yang sudah dipetakan permasalahannya seperti prediksi iklim sulit, hama penyakit masih tinggi dan air sulit pada musin gadu dengan daya dorong yang kuat menyediakan irigasi dan embun bisa teratasi. Kemudian didukung dengan lembaga yang terlibat memberikan daya dorong sehingga tidak ada ketergantung pada lembaga tertentu, dari sebelas lembaga yang berperan penting sebagi pelaku pada PTT yang menjadi pelaku utama Dinas Pertanian dan BPTP.

\section{DAFTAR PUSTAKA}

Eriyatno. 1998. Ilmu sistem meningkatkan mutu dan efektifitas manajemen. Bogor: IPB Press.

Eriyatno dan Sofyar F. 2007. Riset Kebijakan. Metode Penelitian untuk Pascasarjana. IPB Press. 
FAO and World Bank. 2000. Agricultural Knowledge and Information Systems for Rural Development (AKIS/RD). Strategic Vision and Guiding Principles.

Herjanto. 2011. Perencanaan Pengajaran. Retrieved from repository.upi.edu/13181/ 12/S_PLS_0909037_Bibliography.pd

Kasumbogo. 2012. pembanguan pertanian berkelanjutan. Retrieved from http://kasumbogo. staff.ugm.ac.id/index.pp

Kholil. 2005. Rekayasa Model Sistem Dinamik Pengelolaan Sampah Terpadu Berbasis Nirlimbah (Zero Waste). Studi Kasus di Jakarta Selatan (Disertasi). IPB.

Litbang, B. 2007. Pedoman umum pelaksanaan pengelolaan tanaman terpadu (PTT) padi sawah. Jakarta Selatan.

Litbang, B. 2009. Pedoman umum pelaksanaan pengelolaan tanaman terpadu (PTT) padi sawah. Jakarta Selatan.

Litbang, B. 2015. Padi varietas unggul sistem tanam jajar legowo. Jakarta Selatan.

Little, S., P. Q. and T. R. 2002. Managing Knowledge. London: An Essential Reader. Sage.

Novizan. 2005. Petunjuk Pemupukan yang Efektif. Jakarta: Agro Media Pustaka.

Sarlan, A.R., S. Karsono, M. Yamin Samaullah, H. Sembiring, B.S. Effendi, A. D. dan E. S. N. 2012. Prosedur Operaional Standar (POS) Budi Daya Padi Sawah. Balai Besar Penelitian Tanaman Padi.

Saxena J.P., S. and V. P. 1994. Scenario building: a critical study of energy conservation in the Indian cement industry. Technological Forecasting and Social Change, 41(2), 121-146.

Soerjono Soekanto. 2010. Sosiologi Suatu Pengantar. Retrieved from digilib.uinsby. ac.id/2958/8/Daftar Pustaka. pdf

Sumodiningrat, G. 2000. Pembangunan Ekonomi melalui Pengembangan Pertanian. (Eds.1). Jakarta: PT. Bina Rena Pariwara.

Suprihatno B dan A.A. Daradjat. 2008. Kemajuan dan Ketersediaan Varietas Unggul Padi. Padi. Inovasi Teknologi dan Ketahanan Pangan Buku I. Sukamandi. Sukamandi: Balai Besar Penelitian Tanaman Padi.

Sutejo, M. 2002. Pupuk dan Cara Pemupukan. Jakarta: Rineka Cipta.

Turner, M. R. 1996. Problems of privatizing the seed supply in self-pollinated garin crops. In: H. van Amstel, J. W. T. Bottema, M. Sidik and C. E. Van Santen (eds.). Integrating Seed Systems for Annual Food Crops. CGPRT No. 32.

Wordpress. 2016. Agriculture Sustainable-Pertanian Berkelanjutan, Agricultue Sustainable pertanian berkelanjutan di simpang dalam pembanguan pertanian. Retrieved from http://h0404055.wordpress.com 